\title{
NAPELEM HÖMÉRSÉKLETFÜGGÉSÉNEK KÍSÉRLETEN ÉS SZIMULÁCIÓN ALAPULÓ VIZSGÁLATA
}

\author{
Bodnár István
}

\begin{abstract}
Absztrakt: A tanulmány a napelem-karakterisztikák hőmérsékletfüggését mutatja be, hủtött és hütés nélküli napelemek laboratóriumi és szimulációs vizsgálatán keresztül. A napelemek által leadott villamos energia feszuiltségét és áramának erősségét a hőmérsékletváltozás jelentös mértékben befolyásolja. A hömérséklet növekedésének eredményeként az üresjárati és a terhelt napelem kapocsfeszültsége egyaránt csökken, amely közvetlenül teljesítménycsökkenést és hatásfokromlást eredményez. A besugárzó fény intenzitásának növekedése lineárisan növeli a napelem által leadott áramot, aminek következtében a napelem hömérséklete az átfolyó áramok négyzetével arányosan nő, amely végeredménye a feszültség csökkenés, azaz a hatásfok romlása. Mindezek kiküszöbölése érdekében szükséges a napelem hömérsékletének csökkentése. A dolgozatban különböző hömérsékleten végzett mérésekhez tartozó jelleggörbék kerülnek bemutatásra.
\end{abstract}

\begin{abstract}
This paper presents the temperature dependence of solar cell characteristics by laboratory measurements and numerical simulation in case of cooled and non-cooled solar cells. The voltage and current level of electricity, provided by solar cells are highly influenced by the temperature change. The output voltage level of both an idle and a loaded solar cell is decreased by the temperature increase which also leads to power decrease and efficiency deterioration. The intensity increase of the irradiating light linearly increase the current, provided by the power cell which highly increase the temperature of the solar cell and that leads to voltage decrease and efficiency deterioration too. To prevent these processes, it is needed to reduce the temperature of the solar cells. The measured characteristic curves at different temperatures are presented in this paper.
\end{abstract}

Kulcsszavak: napelem, hőmérsékletfüggés, karakterisztika, napszimulátor

Keywords: photovoltaic, solar cell, temperature dependence, characteristic, solar simulator

\section{Bevezetés}

Világunk egyik központi eleme az energia. Manapság egyre jobban előtérbe kerülnek a megújuló energiaforrások, legföképpen Földünk éltető eleme, a Nap, tehát aktuális téma a napenergia számunkra előnyös átalakítására szolgáló berendezések vizsgálata. A Nap nemcsak minden földi élet fenntartója, hanem egész naprendszerünk központi égiteste, amelyben fúziós folyamatok zajlanak le. Hidrogén atomok egyesülnek hélium atomokká, amely reakció során fellépő tömegveszteség (4 millió tonna/sec.), energiává alakul át. $1 \mathrm{~kg}$ hélium képződésekor körülbelül 180 millió $k W h$ energia szabadul fel. A Föld atmoszférájának határára a Napból $1,37 \mathrm{~kW} / \mathrm{m}^{2}$ energiájú sugárzás érkezik, ezt nevezzük napállandónak. A napsugárzás energiája jelentős mértékben lecsökken mire a földfelszínre ér, így maximálisan $1.000 \mathrm{~W} / \mathrm{m}^{2}$ fényintenzitás tapasztalható szép, napos nyári időben (Göőz, 2007).

A Napból érkező, a felső légkört elérő energiát tekintve 100\%-nak, a földfelszínt $33 \%$ direkt- és $18 \%$ szórt sugárzás éri el. A kettő összege adja a globálsugárzás értékét, amelynek a $10 \%$-át a felszín visszaveri és ennek csak $5 \%$-a nyelödik el a légkörben, a többi a világürbe távozik. A sugárzás összetétele jelentős szerepet játszik a hasznosíthatóságában (Gööz, 2007). 
A napenergia hasznosításának két fö irányvonalát különböztetjük meg. Ezek az úgynevezett passzív és aktív hasznositási formák. A passzív napenergia felhasználás lényegében az épületek energiamérlegének az energiafelhasználás szempontjából a legkedvezőbb irányba történő befolyásolása. Már az ókori időktől fogva megfigyelhető a tudatosság az épületek tájolásában és kialakításában, azzal a céllal, hogy a napsugárzás pozitív hatásait kihasználják.

Az aktív napenergia-hasznosítás eszköztára széles skálán mozog. Az erőművi célokra kifejlesztett módszerektől kezdve az egészen kicsi, lakossági felhasználókat kiszolgáló berendezésekig lehetőség van a Nap energiájának hasznosítására. Az energia-átalakítási folyamat végeredménye alapján a napenergia-átalakító berendezések két típusát különböztetjük meg. A napkollektorok használati melegvizet állítanak elö, valamilyen technológiai vagy lakossági célú felhasználásra, a napelemek villamos energiát termelnek. E berendezések közül a napelem az, amely energiatermelését a legnagyobb mértékben befolyásolja a sugárzás típusa. Míg a napkollektorok a szórt sugárzást is kedvező hatásfokkal, addig a napelemek jellemzően csak a direkt sugárzást tudják hasznosítani. A müködésüket a napsugárzás összetétele és intenzitása mellett a környezeti, valamint az üzemi hőmérséklet is befolyásolja, ezért vált szükségessé a vizsgálatuk.

\section{A napelemek müködése, helyettesítő kapcsolása és karakterisztikája}

A napelemek olyan berendezések, amelyek a napenergiából közvetlenül villamos energiát képesek elöállítani, müködésük alapja a fényelektromos hatás. Lakossági és ipari felhasználásban is egyre nagyobb számban alkalmazzák őket. Fejlödésük következményeként hatásfokuk egyre növekszik, míg elöállítási költségük csökken.

A típusától függően a napelem hatásfoka elérheti a $22 \%$-ot is. A jelenleg használt napelemek döntő többsége szilícium félvezetőkön alapszik, de folyamatos kutatások irányulnak új technológiák fejlesztésére, amelyekkel az eddigi maximális hatásfokok javíthatók. A napelemeknek három típusa terjedt el: az amorf, amely átlagos hatásfoka $5-8 \%$, a polikristályos, ami $8-13 \%$ hatásfokkal müködik és a monokristályos, amely hatásfoka meghaladhatja a 13-18\%-ot (Kovács, 2008).

\subsection{Napelem áramerősségének és feszuiltségének hőmérsékletfüggése}

A megvilágítás hatására a napelem kivezetésein $U_{i i}$ üresjárási feszültséget és $I_{r}$ rövidzárási áramot mérhetünk. Ha terhelést kötünk a napelem sarkaira, akkor $U$ feszültséget és $I$ áramot tapasztalhatunk, amelyek rendre kisebbek, mint a terhelés nélküli esetben tapasztalt értékek. A kivezetéseken mérhetö $I$ áram az $I_{\text {foto }}$ fotoáram

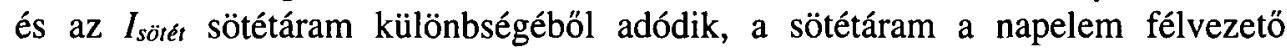
jellegéből adódóan exponenciálisan függ a hőmérséklettől és lineárisan az $I_{s}$ telítési áramtól, ezt a (1)-es képlet írja le (Szász, 2017; Dubey et al., 2013):

$$
I=I_{\text {foto }}-I_{\text {sötet }}=I_{\text {foto }}-I_{s}\left[\exp \left(\frac{e U}{k T}\right)-1\right]
$$


A napelem egyszerüsített, elektronikai modellje, minden ohmikus és kapacitív jellegü elemet elhanyagolva egy diódából és egy vele párhuzamosan kötött áramgenerátorból áll, amely által előállított áram áramerőssége a megvilágítás mértékétől függ. Ezt a modellt és a korábbiakban említett $I, I_{\text {sötét, }} I_{\text {foto }}$ áramirányokat a 1.-es ábra tartalmazza.

\section{1. ábra: Ideális, terheletlen napelem modellje}

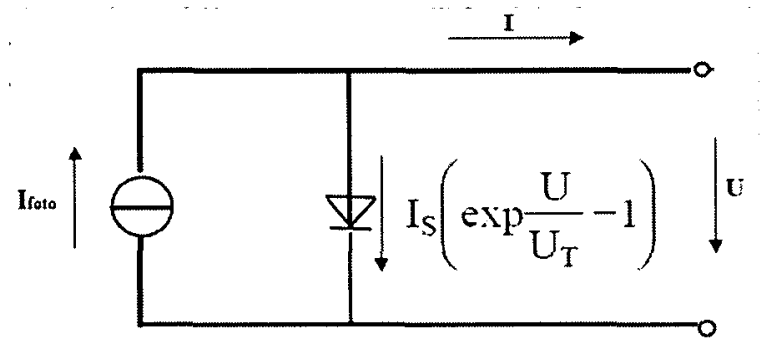

Forrás: Kovács (2008) és Mizsei (2003) nyomán

Az $U=0$, illetve az $I=0$ behelyettesítéssel könnyen kifejezhető a rövidzárási áram (2) és az üresjárási feszültség (3). Az üresjárási feszültség logaritmikusan függ az áramviszonyoktól és lineárisan az $U_{T}$ hőmérsékletfüggö termikus feszültségtől. Ennek megfelelöen (King et al., 1997):

$$
\begin{gathered}
I_{r}=I_{\text {foto }} \\
U_{\ddot{\mathrm{u}}}=\frac{k T}{e} \ln \left(\frac{I_{\text {foto }}}{I_{s}}+1\right)=U_{T} \ln \left(\frac{I_{\text {foto }}}{I_{s}}+1\right)
\end{gathered}
$$

Amennyiben a napelem valóságos elektronikai modelljét tekintjük, akkor a veszteségek nem hanyagolhatóak el. Ekkor a diódák parazitakapacitását jelképezvén egy kondenzátort kötünk párhuzamosan a diódával. A belső ellenállás és a vezetékek ellenállását egy-egy soros és párhuzamos ohmos ellenállás jelképezi. A napelem valós elektronikai modellje a 2. ábrán látható.

\section{2. ábra: Napelem valóságos elektronikai modellje}

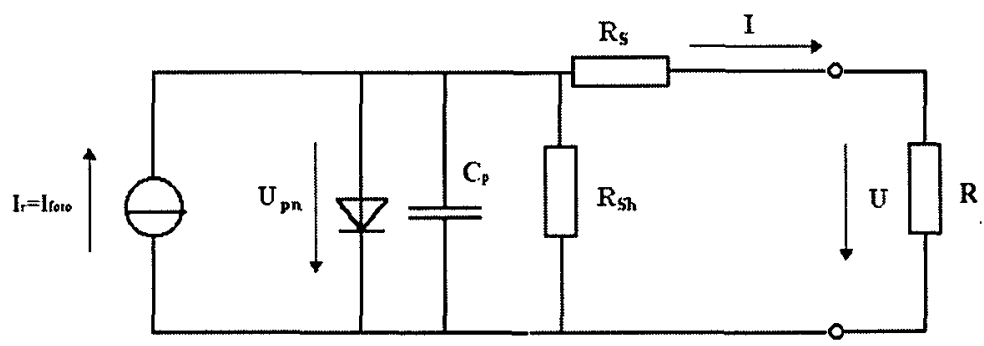

Forrás: Kovács (2008) és Mizsei (2003) alapján 
A 3. ábrán megfigyelhetők az $U-I$ karakterisztikák eltérő fényintenzitások esetén. Látható, hogy a rövidzárási áram egyenesen arányos a megvilágítás erősségével, hisz a fotoáram nagysága a fényintenzitással nő és a (2) képlet kimondja, hogy a fotoáram megegyezik a rövidzárási árammal. A (3) összefüggésből láthatjuk, hogy a kivezetéseken mérhetö üresjárási feszültség pedig logaritmikusan függ a felületre érkező fényintenzitás nagyságától.

\section{3. ábra: Napelem feszültség-áramerősség jelleggörbéi különböző fényintenzitások esetén}

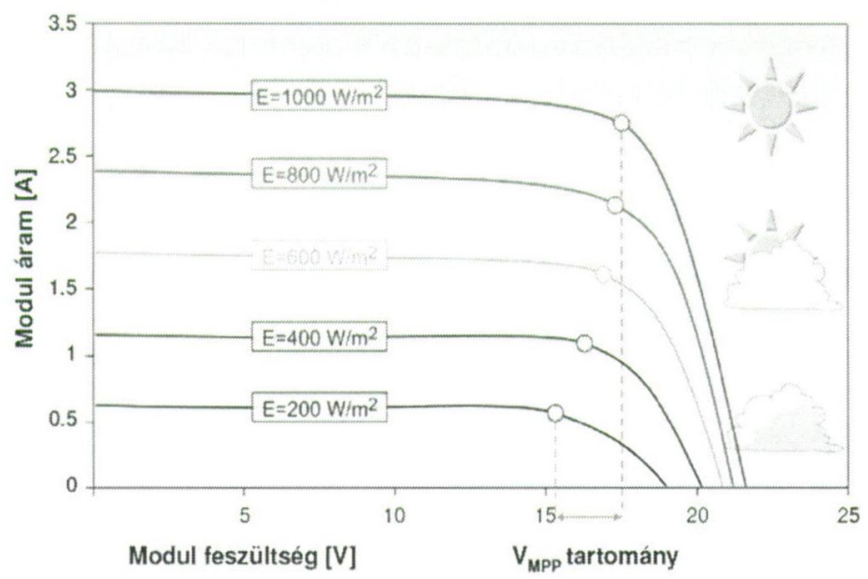

Forrás: Armin (2002)

\subsection{Teljesítmény és hatásfok függése a hőmérséklettől}

A napelem kapcsaira kapcsolt $R$ ellenállással modellezhető terhelésen átfolyó $I$ áramerősség és a rajta eső $U$ feszültség szorzataként számolható a napelem hasznos P teljesítménye (Szász, 2017):

$$
P=I U=I_{r} U-I_{S} U \exp \left(\frac{U}{U_{T}}-1\right)
$$

A napelemről az adott megvilágítás mellett a maximális teljesítmény levétele terhelésillesztési feladattal oldható meg. A (4) összefüggés szélsőértékének megkereséséhez parciálisan deriváljuk a függvényt U szerint és keressük a $\frac{\partial P}{\partial U}=0$ egyenlet megoldását. Ebből kifejezhető a maximális teljesítményhez tartozó munkaponti- $I_{m}$ áramerősség (5) és $U_{m}$ feszültség (6) (Szász, 2017):

$$
\begin{gathered}
I_{m}=-\frac{U_{m}}{U_{T}} I_{s} \exp \frac{U_{m}}{U_{T}} \approx-I_{r}\left(1-\frac{U_{T}}{U_{m}}\right) \\
U_{m}=U_{0}-U_{T} \ln \left(1+\frac{U_{m}}{U_{T}}\right)
\end{gathered}
$$


Az Ohm törvény alapján az (5) egyenletből kifejezhető az optimális $R_{m}$ terhelés értéke (Szász, 2017):

$$
R_{m}=-\frac{U_{m}}{I_{m}}=\frac{U_{T}}{I_{s} \exp \left(\frac{U_{m}}{U_{T}}\right)}=\frac{U_{T}}{I_{m}+I_{s}+I_{r}}
$$

A terhelö ellenállás értéke ideális esetben megegyezik a napelem belső ellenállásának az értékével. Az úgynevezett $\varphi$ térkitöltési tényező mutatja meg azt, hogy a munkaponti feszültség- és áramerősség szorzata hogyan viszonyul az üresjárati feszültség- és a rövidzárlati áramerősség szorzatához:

$$
\varphi=\frac{U_{m} I_{m}}{U_{i u} I_{r}}
$$

A térkitöltési tényező, vagy más néven forma tényezö (fill factor) értéke függ a napelem megvalósításától és a megválasztott munkaponttól. A $\varphi$ értéke a gyakorlatban használt napelemek esetén 0,75 és 0,85 értékek között mozog. A térkitöltési tényezỏ megmutatja, hogyan aránylik egymáshoz a maximálisan levehető teljesítmény az $I_{r} \cdot U_{\mathrm{Ü}}$ szorzat által meghatározott elméleti teljesítményhez.

A napelem modul $\eta_{\max }$ maximális hatásfoka a napelem által leadott maximális

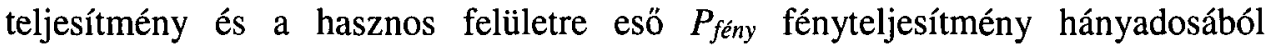
számítható ki (Szász, 2017):

$$
\eta_{\text {max }}=\frac{I_{m} U_{m}}{P_{\text {fény }}}=\frac{\varphi I_{r} U_{\ddot{u}}}{P_{f e ́ n y}}
$$

\subsection{Hőmérséklet és intenzitás hatása az áramerősségre és feszültségre}

A napelem $T_{U}$ üzemi hömérséklete az alábbi (9) összefüggéssel határozható meg:

ahol:

$$
T_{\ddot{U}}=\left(T_{N}-T_{K}\right) \cdot \frac{E_{\text {int }}}{E_{S T C}}+T_{K}
$$

$T_{N}=$ a napelem névleges hömérséklete $(\mathrm{K})$,

$T_{K}=$ a környezeti hömérséklet $(\mathrm{K})$,

$E_{\text {int }}=$ a megvilágítás intenzitása $\left(\mathrm{W} / \mathrm{m}^{2}\right)$,

$E_{S T C}=$ a standard méréshez tartozó intenzitás $\left(1.000 \mathrm{~W} / \mathrm{m}^{2}\right)$.

Ezek figyelembevételével meghatározható a fotóáram a hőmérséklet függvényében (Dubey et al., 2013; King et al., 1997):

$$
I_{\text {foto }}=I_{S C N} \cdot\left[1+\mu_{I S C} \cdot\left(T_{\ddot{U}}-T_{K}\right)\right]=I_{S C N}+K_{I S C} \cdot\left(T_{\ddot{U}}-T_{K}\right)
$$


ahol:

$I_{S C N}=$ a standard méréshez tartozó rövidzárlati áramerösség (A),

$\mu_{I r}=$ a rövidzárási áram százalékos hőmérsékleti együtthatója $(\% / \mathrm{K})$,

$K_{I S C}=$ a rövidzárási áram hömérsékleti együtthatója $(\mathrm{A} / \mathrm{K})$.

Amennyiben az intenzitás is változik, a fotóáram értéke az alábbiak szerint írható le (King et al., 1997):

$$
I_{\text {foto }}=\frac{E_{\text {int }}}{E_{S T C}} \cdot I_{S C N} \cdot\left[1+\mu_{I r} \cdot\left(T_{\dot{\mathbf{u}}}-T_{K}\right)\right]=\frac{E_{\text {int }}}{E_{S T C}} \cdot I_{S C N}+K_{I S C} \cdot\left(T_{\ddot{U}}-T_{K}\right) .
$$

Az (11) összefüggés alapján elmondható, hogy a megvilágítás intenzitása és a hömérséklet változása is lineárisan befolyásolja a napelemen átfolyó áram erösségét, amiről arra lehet következtetni, hogy ha nő a megvilágítás intenzitása, és/vagy a napelem hőmérséklete, akkor a feszültég csökken, így a napelem hatásfoka is csökken.

A telítési áram értéke a hỏmérséklet függvényében a két dióda modell alapján írható fel (13) (Szász, 2017).

ahol:

$$
I_{s}=\frac{I_{\text {foto }}}{\left[\exp \left(\left(\frac{e \cdot U_{O C}}{n \cdot k \cdot T \cdot N_{s}}\right) \cdot\left(1+\mu_{U O C} \cdot\left(T_{\tilde{U}}-T_{K}\right)\right)\right)\right]-1}
$$

$\mu_{U O C}=\mathrm{az}$ üresjárati feszültség százalékos hőmérsékleti együtthatója $(\% / \mathrm{K})$,

$e=$ az elektron töltése $\left(1,60 \cdot 10^{-19} \mathrm{C}\right)$,

$n=$ Dióda idealizáltsági faktor, a 2-dióda modell alapján értéke 2,

$k=$ Boltzmann állandó $\left(1,38 \cdot 10^{-23} \mathrm{~J} / \mathrm{K}\right)$,

$N_{s}=$ Sorosan kapcsolt cellák száma $(18 \mathrm{db})$.

Az üresjárati feszültség hőmérsékletfüggése (King et al., 1997): ahol:

$$
U_{O C T}=U_{O C N} \cdot\left[1+\mu_{U O C} \cdot\left(T_{S}-T_{A}\right)\right]=U_{O C N}+K_{U O C} \cdot\left(T_{S}-T_{A}\right),
$$

$K_{U O C}=$ az üresjárati feszültség hőmérsékleti együtthatója $(\mathrm{V} / \mathrm{K})$.

\section{A mérési összeállítás}

A napelem egy vele megegyező méretü asztalon lett elhelyezve úgy, hogy a napelem két rövidebb széle alá egy-egy $50 \mathrm{~mm}$ vastagságú falecet helyeztem, ezzel kialakítva egy áramlási csatornát a napelem hátlapja és az asztallap között. A hűtésre szolgáló hideglevegőt egy Orion CSHP 9001 C4 típusú mobil klíma biztosította. A klímából kiáramló hideg levegőt a már korábban említett áramlási csatornához mủanyag fólia 
segítségével vezettem, amelyek puffer-térként is viselkedve kellően egyenletessé tették az áramlást.

Előzetes hőmérsékletvizsgálatok azt mutatták, hogy a napelem hátlapja hasonló mértékben felmelegszik, mint az abszorber felülete. E tapasztalat alapján elmondható, hogy a napelem hátlapján is lehetőség van hőenergia elvonására, tehát e hütési eljárás működőképessége megalapozott volt. A megvalósított berendezés az 4. ábrán látható.

A napelem felületének hőmérsékletét egy $Y C-747 D$ típusú négycsatornás digitális hőmérővel mértem. A négy érzékelőt a napelem négy különböző pontjára helyeztem el. A továbbiakban a négy vizsgált pont átlagából képzett hőmérsékletet tekintettem a napelem hőmérsékletének. Az érzékelőket az eredmények pontossága miatt jó hővezető tulajdonságú alumínium szalaggal rögzítettem a napelem felületéhez, ügyelve arra, hogy a kitakart felület nagysága elhanyagolhatóan kicsi legyen.

\section{4. ábra: Mérési elrendezés}
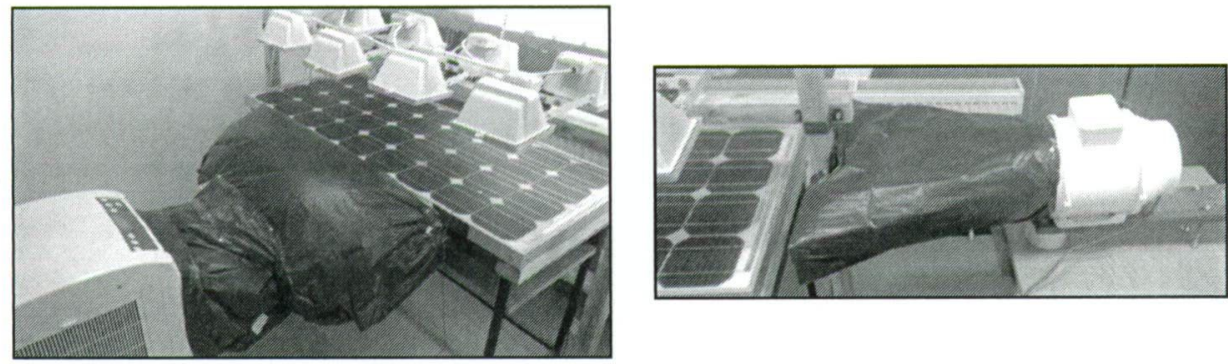

Forrás: saját szerkesztés

A megvilágított napelem átlaghőmérséklete hütés nélkül elérte a $80^{\circ} \mathrm{C}$-ot. Ezzel az eljárással a napelem hőmérsékletét $15^{\circ} \mathrm{C}$-kal sikerült lecsökkentenem. A további hűtés érdekében a napelem abszorber felületén próbáltam hőt elvonni, amihez egy TT 150 típusú csőventilátort használtam fel. A reflektortartó állványhoz rögzített drótkeret (mint kivezető nyílás) és a ventilátor közt az áramlási csatornát a már korábban is használt műanyag fólia segítségével alakítottam ki. E megoldás kiszélesítette az áramlási teret, így a napelem nagyobb felületén érvényesült a hütő hatás, viszont hátrányként meg kell említeni, hogy kis mértékben lelassította az áramlást. A klíma és a ventilátor együttes használata esetén a napelem átlaghőmérséklete $40^{\circ} \mathrm{C}$-kal csökkent.

Ezután a ventilátor kivezetésén kiáramló levegöt közvetlenül a napelem felületére irányítottam, tehát nem alkalmaztam a korábbiakban bemutatott terelöt. Ez esetben az áramlás sebessége nem csökkent és további $10^{\circ} \mathrm{C}$ hömérsékletcsökkenést sikerült elérni. Tehát a klíma és a ventilátor ilyen módú együttes használata $50^{\circ} \mathrm{C}$-os hőmérsékletcsökkenést eredményezett. Ekkor a napelem átlaghőmérséklete $30^{\circ} \mathrm{C}$ volt.

A napelem terhelését egy nagyteljesítményü tolóellenállással modelleztük, amelynek ellenállása mérések alapján $0,7-7,2 \Omega$ értékek közt volt változtatható. A 
napelem által elő́llított feszültség és áramerősség egyidejü méréséhez egy Protek DM-301 és egy METEX M-365OD típusú digitális multimétert használtam.

\section{A szimuláció alapadatai, alapvetései és az elhanyagolások}

A numerikus szimuláció az előző fejezetekben említett két-dióda modell egyenletrendszerének felhasználásával készült. A szimuláció során a napelem egyszerüsített áramköri modelljéből indultam ki. A vizsgált napelem alapadatait az 1. táblázat tartalmazza.

\section{1. táblázat: A vizsgált napelem alapadatai}

\begin{tabular}{|l|c|c|}
\hline \multicolumn{1}{|c|}{ Paraméter } & Jelölés és mértékegység & Érték \\
\hline Gyártási év & - & 2008 \\
\hline Csúcsteljesítmény & $\mathrm{P}_{\max }[\mathrm{W}]$ & 85 \\
\hline Munkaponti áramerösség & $\mathrm{I}_{\mathrm{M}}[\mathrm{A}]$ & 4,88 \\
\hline Munkaponti feszültség & $\mathrm{U}_{\mathrm{M}}[\mathrm{V}]$ & 17,45 \\
\hline Rövidzárási áramerősség & $\mathrm{I}_{\mathrm{SC}}[\mathrm{A}]$ & 5,40 \\
\hline Üresjárati feszültség & $\mathrm{U}_{\mathrm{OC}}[\mathrm{V}]$ & 21,20 \\
\hline Formatényezö & $\varphi[-]$ & 0,74 \\
\hline Soros ellenállás & $\mathrm{R}_{\mathrm{S}}[\Omega]$ & 0,0035 \\
\hline Párhuzamos ellenállás & $\mathrm{R}_{\mathrm{P}}[\Omega]$ & 10.000 \\
\hline Sorosan kapcsolt cellák száma & $\mathrm{N}_{\mathrm{S}}[\mathrm{db}]$ & 18 \\
\hline Párhuzamosan kapcsolt cellák száma & $\mathrm{N}_{\mathrm{P}}[\mathrm{db}]$ & 2 \\
\hline Teljesítmény hömérsékleti együttható & $\mathrm{K}_{\mathrm{PM}}\left[\mathrm{W} /{ }^{\circ} \mathrm{C}\right]$ & $-0,391$ \\
\hline Rövidzárási áram hömérsékleti együttható & $\mathrm{K}_{\mathrm{ISC}}\left[\mathrm{A} /{ }^{\circ} \mathrm{C}\right]$ & 0,001674 \\
\hline Üresjárati feszültség hömérsékleti együttható & $\mathrm{K}_{\mathrm{UOC}}\left[\mathrm{V} /{ }^{\circ} \mathrm{C}\right]$ & $-0,073776$ \\
\hline Csúcshatásfok & $\eta[\%]$ & 12.75 \\
\hline $\begin{array}{l}\text { Normál müködési körülményekre vonatkozó } \\
\text { hőmérséklet }\end{array}$ & $\mathrm{T}_{\mathrm{N}}\left[{ }^{\circ} \mathrm{C}\right]$ & 25 \\
\hline A megvilágítás intenzitása & $\mathrm{E}_{\mathrm{int}}\left[\mathrm{W} / \mathrm{m}^{2}\right]$ & 861 \\
\hline
\end{tabular}

Forrás: saját szerkesztés

A szimuláció során az alábbi megfontolásokkal és elhanyagolásokkal éltem:

- a napelem-modult egy cellára redukáltam,

- elhanyagoltam a soros és a párhuzamos ellenállást,

- a megvilágítás intenzitásának integrált középértékét vettem,

- a gyártó által megadott üresjárati feszültséggel, rövidzárlati áramerősséggel, valamint hőmérsékleti állandókkal számoltam,

- a Napfényhez viszonyítva a halogén reflektor fényének spektrális összetételbeli különbségét (spektrális energiasürüségét) egy konstanssal vettem figyelembe.

Mind a szimulációk, mind pedig a mérések során a hőmérsékleti tranziens hatására bekövetkező paraméterváltozásokat vizsgáltam. Terheletlen napelemes esetében, a mért és szimulált jellemző a rövidzárási áramerősség, az üresjárati feszültség, valamint az elméleti teljesítmény. 


\section{A mérési eredmények bemutatása}

A tranziens vizsgálatot terheletlen napelemen végeztem el, mégpedig úgy, hogy a megvilágítás bekapcsolásával egyidejűleg működésbe hoztam a mobil klímás hűtési rendszert. 20 percen keresztül mértem percenként a napelem négy pontján tapasztalható hőmérsékletet, a cellák által generált üresjárati feszültséget és rövidzárási áramot (1. szakasz). Ezután kikapcsoltam a hủtési rendszert és 10 percen keresztül 10 mérési pontban ismételtem a mintavételezést (2. szakasz).

Miután a napelem hőmérséklete állandósult a korábbiakban ismertetett csőventilátoros hủtés beiktatása segítségével a napelemet visszahütöttem a kiindulási hőmérsékletre (3. szakasz). A hőmérséklet-idő, a feszültség-idő és az áramerősségidő grafikonokat az 5. ábra tartalmazza.

\section{5. ábra: A hőmérséklet, az üresjárati feszültség és a rövidzárlati áramerősség megjelenítése az idő függvényében}

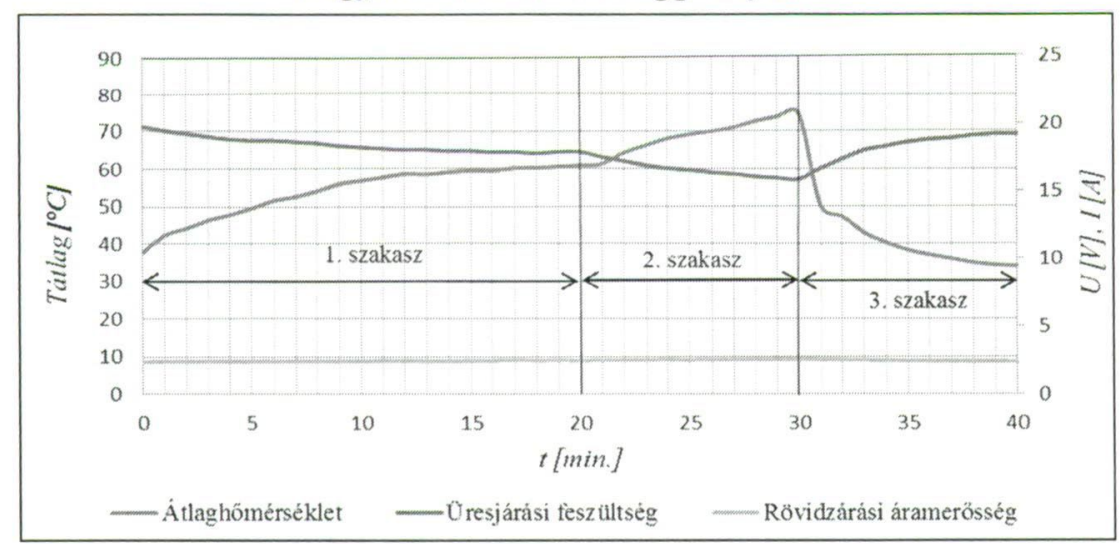

Forrás: saját szerkesztés

Látható, hogy a hőmérséklet növekedésének hatására az üresjárati feszültség csökkent, míg az áramerösség csak kismértékben növekedett. Fordított esetben, mikor a napelem lehült a feszültség nőt, az áramerősség pedig csökkent, hasonló mértékben. Tehát e kísérlet során igazolni tudtam a szakirodalom által leírt jelenséget.

A vizsgálat során a hőmérséklet változására bekövetkező elméleti teljesítményváltozást a 6 . ábrán figyelhetjük meg. Az tapasztalható, hogy az elméleti teljesítmény a hőmérséklet változásával ellentétesen alakul. E jelenség az 5. ábrán bemutatott üresjárati feszültség és rövidzárási áramerősség hőmérséklet-függése és az elméleti teljesítmény számítási módja (4) alapján feltételezhető volt.

$\mathrm{Az}$ a következtetés vonható le, hogy a hőmérséklet növekedésével a napelem hatásfoka, és ezen keresztül a teljesítménye is csökken. A természetben elöforduló $1.000 \mathrm{~W} / \mathrm{m}^{2}$ napsugárzás-intenzitás mellett a napelem felületi hőmérséklete meghaladhatja a $80^{\circ} \mathrm{C}$ hőmérsékletet, így a hatásfokromlás jelentős teljesítménycsökkenést eredményez. A téli időszakban a napelem hütése biztosított, így télen jobb hatásfokkal képes működni, mint a nyári nagy melegben. 


\section{6. ábra: Az elméleti teljesítmény és a hőmérséklet megjelenítése az idő} függvényében

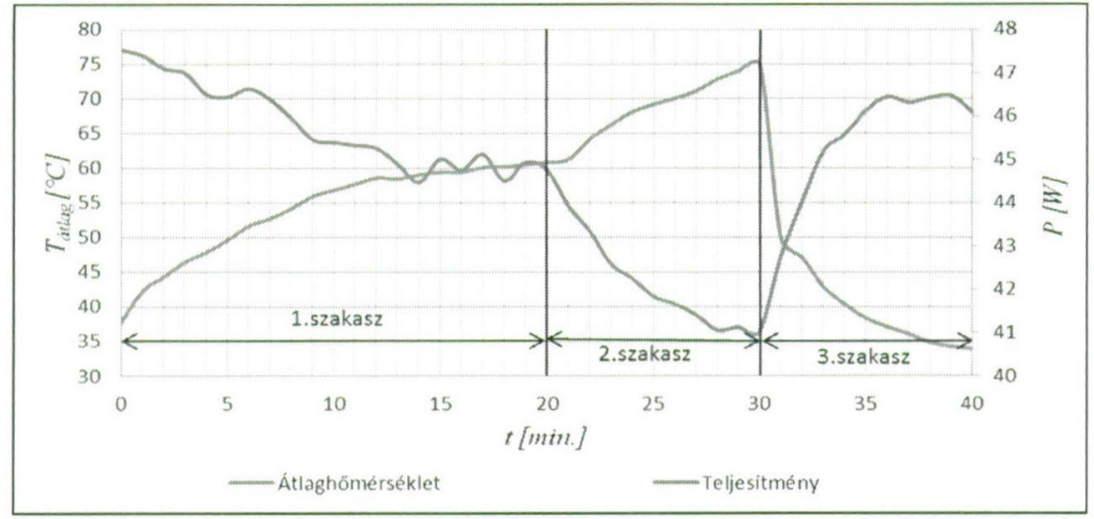

Forrás: saját szerkesztés

\section{A mérési- és a szimulációból származó eredmények összehasonlítása}

A következő ábrákon rendre összehasonlítom a mért és a szimulált eredményeket.

A 7. ábrán a rövidzárlati áramerősség látható a hőmérséklet (idő) függvényében. Minden egyes lépték egyben egy perc elteltét is jelenti, így a görbéken időbeli lefutás is értelmezhetö.

Megfigyelhető, hogy a mérési eredmények alapján vázolt áramerősséghőmérséklet (idő) görbe jelleghelyesen követi a katalógusadatok felhasználásával készült numerikus szimuláció alapján vázolt görbét. A szimulált és a mért adatok közötti időátlagolt eltérés $4,14 \%$ a szimuláció javára. Mindkét görbe esetében elmondható, hogy a hőmérséklet függvényében a vártaknak megfelelő áramerősségváltozás következett be. A napelem hütése nélkül az áramerősség nőt, hütéssel csökkent.

7. ábra: A napelem rövidzárási áramerőssége a hőmérséklet (idő) függvényében

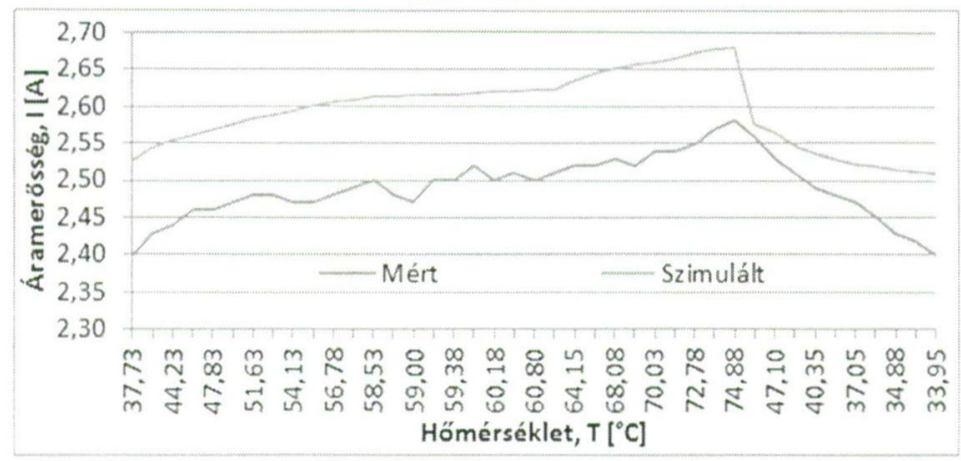

Forrás: saját szerkesztés 
Az üresjárati feszültég hőmérsékletfüggése a 8. ábrán látható. Megfigyelhető, hogy a mért értékekre fektetett trendvonal a napelem hütése nélküli esetben, illetve az erős hütés alkalmazásánál a modell görbéjéhez simul. Gyenge hütés esetében a két görbe között nagyobb eltérés tapasztalható. A modell időátlagban 5,98\%-kal becsüli túl a mért eredményeket.

\section{8. ábra: A napelem üresjárati feszültsége a hőmérséklet (idő) függvényében}

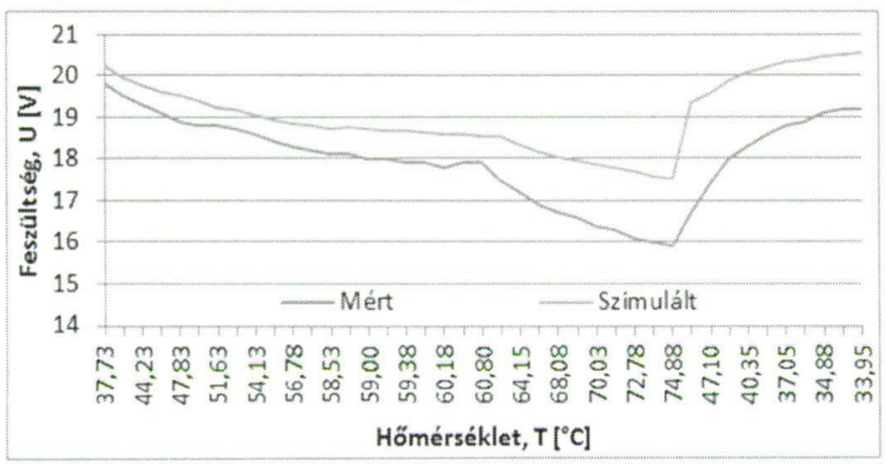

Forrás: saját szerkesztés

Az elméleti teljesítmény grafikonok a 9. ábrán láthatók. Egyértelmüen megállapítható, hogy az elméleti teljesítmény a napelem felületi hőmérsékletének növekedése következtében csökken. E jelenség az elméleti teljesítmény számítási módja (4) alapján feltételezhető volt. A csökkenés oka, hogy a napelem feszültsége nagyobb mértékben csökken, mint amilyen mértékben az áramerőssége nő nagyobb hőmérsékleten üzemelő rendszer esetében. A szimulációs alapmodell 10,34\%-kal becsülte túl az elméleti teljesítményt a mérthez képest. A túlbecslés oka a mérési pontatlanságok mellett arra is visszavezethető, hogy a napelem a vizsgálatok során 7 éves volt, azaz az évek során a kristályszerkezete öregedett, degradálódott.

\section{9. ábra: A napelem elméleti teljesítménye a hőmérséklet (idő) függvényében}

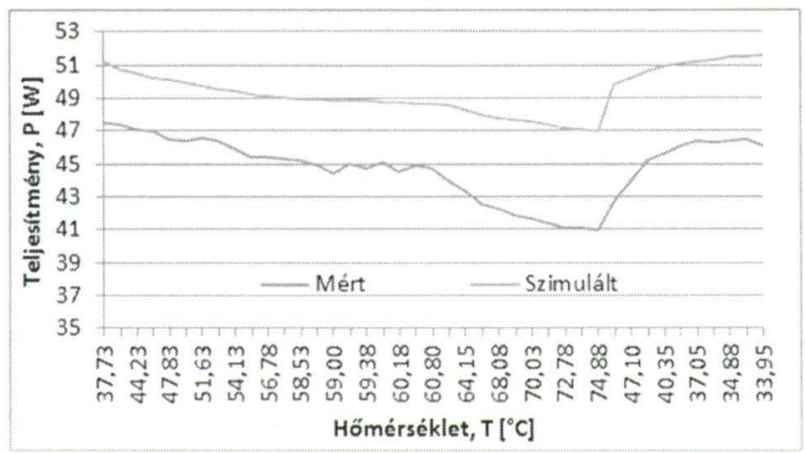

Forrás: saját szerkesztés 


\section{Következtetések, összegzés}

A szimuláció és a mérés célja a hőmérsékleti tranziens során lejátszódó folyamatok feltárása volt. A szakirodalom által leírtak alapján az mondható el, hogy a napelem üresjárati feszültsége jelentősebb mértékben csökken-, a rövidzárási árama kismértékben nő a félvezető anyagának hömérsékletnövekedése által. A feszültség nagyobb mértékben csökken, mint ahogy az áramerösség nő, így a melegedés hatására a napelem elméleti teljesítménye csökken. A mért és a szimulált eredmények a szakirodalomban tapasztaltakat produkálták.

A mérési eredményeket összehasonlítva a szimulációból származó eredményekkel az a következtetés vonható le, hogy a napelem hatásfoka a gyártáskori értékhez képest csökkent. Azonban nem szabad figyelmen kívül hagyni, hogy az eredmények jelentősen függnek a müszerek és a mérési metódus pontatlanságból, a mérési hibáitól, így a kapott százalékos eltérések ezekre is visszavezethetők.

A mért és a számolt adatok közötti eltérésnek pontatlanságok mellett számos oka lehetséges. Az általam használt megvilágítás nem reprodukálja kellő pontossággal a természetben tapasztalható fényviszonyokat (kisebb és nem kellően homogén fényintenzitás, eltérő hullámhossz szerkezet). A spektrális összetételből származó különbségeket a Napszimulátorként használt izzó spektrumának kiméréséböl származtatott tényezővel figyelembe tudtam venni, azonban a fényintenzitás inhomogenitását nem, ennek hatása lehet a kisebb teljesítmény. A napelem öregedése során hatásfok degradáció tapasztalható, amely a teljesítmény csökkenését okozza.

\section{Irodalomjegyzék}

Armin, R. (2002): Napelem technológiák és jellemzőik. PSE Projektgesellschaft Solar Energiesysteme mbH. G04 elöadás, fordította: SzIE.

Dubey, S., Sarvaiya, J. N., Seshadri, B. (2013): Temperature Dependent Photovoltaic (PV) Efficiency and Its Effect on PV Production in the World - A Review. Energy Procedia, 33: 311-321.

Gööz L. (2007): Energetika Jövöidöben. Bessenyei György Könyvkiadó, Nyíregyháza.

King, L. D., Kratohvil, A. J., Boyson, E. W. (1997): Temperature Coefficients for PV Modules and Arrays: Measurement Methods, Difficulties, and Results. 26th IEEE Photovoltaic Specialists Conference, Anaheim, California.

Kovács Cs. (2008): Napelemek müködése és alkalmazásai. Budapest.

Malik, A. Q., Damit, S. J. B. H. (2003): Outdoor testing of single crystal silicon solar cells. Renewable Energy, 28 (9): 1433-1445.

Mizsei J. (2003): Napelemek laboratórium. Segédlet. Budapest.

Szász Cs. (2017): Optimal control of Photovoltaic Modules Energy Efficiency. Journal of Computer Science and Control Systems, 10 (1): 29-34. 